\title{
A SKETCH OF THE VIETNAMESE LANGUAGE AND CULTURE FROM SOUTHEAST ASIAN PERSPECTIVE
}

\author{
Tran Tri Doi* \\ VNU University of Social Sciences and Humanities, \\ 336 Nguyen Trai, Thanh Xuan, Hanoi, Vietnam
}

Received 29 November 2018

Revised 20 May 2019; Accepted 28 May 2019

\begin{abstract}
As a Southeast Asian nation, Vietnam is a miniature of the languages and cultures of the region thanks to its possession of the most typical features of the languages and cultures of various Southeast Asian nations. Through description and comparison using an inter-disciplinary approach, the paper points out that due to Vietnam's special geographical position, its language and culture do contain phenomena which reflect the boundaries of linguistic and cultural features among different subregions in Southeast Asia. Therefore, Vietnam can be regarded as the intermediary for the linguistic and cultural interchange between the North and the South. In other words, from a cultural-linguistic perspective, Vietnam is considered a gateway or a hub of contact among East Asia, Southeast Asia and South Asia."*
\end{abstract}

Keywords: culture, language, Vietnam, Southeast Asia

1. Distinction between "the administrative Southeast Asia" and "the cultural Southeast Asia"

Vietnam is a nation in Southeast Asia (SEA). However, if a full understanding of the Vietnamese language and culture through the SEA lens is sought after, it is necessary to delineate the actual geographical boundaries of this region because the current conceptualization of SEA would not allow the entire dynamic history of the region's languages and cultures to be thoroughly grasped. Therefore, we believe that it is important to distinguish the two concepts

\footnotetext{
Tel.: 84-913588364

Email: ttdoihanh@gmail.com

** This paper is edited from a series of presentations and discussions at seminars and workshops at Guangdong University of Foreign Studies, Beijing University, Honghe University (China) between 2015-2016, the 2nd China-ASEAN Conference in Chongzuo in 2017 and Tokyo University (Japan) in November 2017.
}

of the geo-administrative SEA and the geo-cultural SEA.

\subsection{The Administrative Southeast Asia}

As of 2018, administratively, SEA is a geographical region of 11 states. The concept of SEA in current usage actually made its first appearance on the world political map after the Second World War (WW2) to indicate a specific region in the southeast of the Asian continent. Putting political institutions aside for the moment, nations in this region bear both common regional cultural-linguistic features and their own peculiarities. Nevertheless, historically and culturally speaking, prior to WW2, SEA physical territory was much larger with several subregions. In other words, it must have spanned over part of the territory south of China and part of the territory east of India. Technically speaking, this geographical region of the Asian continent is largely subject to a monsoon climatic regime. That is the reason why we once posited that that expanded 
geographical Southeast Asian region, which humanity researchers consider to be Southeast Asia, should be called "the cultural SEA" (Trần Trí Dõi, 2005, pp.15-29; 2011, pp.14$29)$ or "the ethnic cultural SEA" so as to be distinct from the administrative SEA.

\subsection{The cultural SEA aligned with the development history of the regional culture}

Physically, thanks to its monsoon natural climatic features, cultural SEA possibly covers a much larger geographical area than the current administrative SEA. In the view of various humanity disciplines, this cultural SEA space does contain both relative unity and subregional differences as a result of its history.

The natural boundary of the territory south of China, i.e. the northern subregion of the cultural SEA, almost coincides with the Chang Jiang River (otherwise known as the Yangtze River). This territory Before our Common Era (B.C.E.) was referred to in ancient Chinese documents as the land of the Bách Việt (Băiyuè 百越) inhabitants who spoke non-Sino languages (Trần Trí Dõi, 2017b, pp.41-53). The eastern part of the present India (including part of Bangladesh and Indian states east of the Ganga) is the western part of the cultural SEA. This geographical region was once believed to be the original birthplace of the Austroasiatic language family (Sidwell, 2010, p. 119). On such a scale, the cultural SEA is naturally distinct from adjacent regions thanks to major rivers, e.g. the Ganga (India) and the Chang Jiang (China), which possess crucial cultural values to the whole region both in history and at present, and assume critical geographical location both within and outside the cultural SEA.

With such boundaries, the cultural SEA occupies a much larger part of Asia than the present administrative SEA. In other words, this is an expanded SEA which deserves due attention from various humanity disciplines, including linguistics and cultural studies, and in fact, attention has been paid by various scholars in humanities. In Vietnam, for instance, from a cultural-archeological perspective, Hà Văn Tấn wrote, 'In prehistory and early history, the land south of the Yangtze should be regarded as belonging to the cultural SEA rather than East Asia' (Hà Văn Tấn, 1981, p.186). In a similar archeological vein, Trình Năng Chung analyzed the influence of Vietnam's Dong Son culture on Liangguang in south China (Trình Năng Chung, 2014, pp. 201-215). Meanwhile, in his writing about Vietnam's history and geography, Đào Duy Anh says that in China, "the book Độc sư phuơng du kỷ yếu by Cố Tổ Vũ published in 1667, volumes 106 to 112 on Guangxi, does contain an annex of geographical records on our country' (i.e. Vietnam). When explaining the history of Cổ Loa (古螺), a national capital in Vietnam's history, he also used Từ Tùng Thạch (徐松石, Xu Songshi)'s conclusions in the latter's study of geographical names in south China (1946) in his arguments.

According to such archeological, historical and geographical views, the cultural SEA is a vast area between the Indian and Chinese sub-continents, where different languages and cultures (including the Vietnamese language and Vietnamese culture) maintained regular contact and borrowed from one another, and such borrowings still remain.

Not only Vietnamese humanity scholars have proved that the cultural SEA, as Hà Văn Tấn calls it, includes 'the land south of the Yangtze River', but also foreign researchers in China and in the West, directly or indirectly, posit similar views of SEA. For instance, when describing "Hoa Sơn nhai bích họa (花 山崖壁画)” (Hua mountain rock paintings), which Chinese cultural researchers believe 
to have existed around $2400-2600$ years ago, the two Chinese scholars Hoàng Nhữ Huấn and Hoàng Hỷ (黄汝训-黄喆) comment that the images in those 'paintings' seem to depict 'not only the dances of Lạc Việt (雒 越)'s inhabitants but also their ancient marital customs' (2005). Hoa Son nhai bich họ (Hua mountain rock paintings) are believed to have been made in the Qin-Han dynasties on a rock in the mountain range along the Ming Jiang River (the segment flowing through Ning Ming county of Sùng Tả (Chongzuo Shi) city, Guangxi province). Based on the two Chinese authors' assumptions, it is possible to posit that the dancers depicted in the Hua mountain rock paintings were close to Lạc Việt inhabitants who spoke non-Sino languages. Naturally, one would definitely associate non-Sino Lạc Việt people with a much larger cultural SEA (Trần Trí Dõi, 2017b, pp.41-53). If the identified date of the Hua mountain rock paintings that still remain in Ningming, Guangxi, were correct, the paintings would reveal that in ancient times, this area used to be the cultural area of non-Sino communities associated with SEA in the south today.

Another recent publication on language that is related to Vietnam's history by Kelley (2013) also reflects this view. From a multidisciplinary approach, in which historical perspective is predominant, Kelly utilizes the use of languages in the whole area of south China and north Vietnam as supports to his argument. Specifically, while explaining the historical relation between the Viet community (who spoke a language of the Austroasiatic family) and the Thai (Tai) people (who spoke a language of the Tai-Kadai family) in prehistoric times in the cultural SEA, he posits that the author of Đại Việt sủ ký toàn thu (Complete Book of the Historical Records of Đại Viẹt) written in the $15^{\text {th }}$ century used borrowings from the Tai language. He writes, "In the $15^{\text {th }}$ century a new Vietnamese dynasty, the Lê Dynasty, came to power after the Chinese were driven out in 1427. The Lê Dynasty needed to demonstrate its legitimacy, and it did so through various means" (Kelly, 2013, p. 82), and these means include words borrowed from Tai. Considering the author's explanation in the paper, it is possible for us to assert that Vietnam's cultural and historical issues can be inseparable from linguistic and cultural evolution in the territory south of China, i.e. part of the area we refer to as the cultural SEA.

Another Western researcher - the French scholar Ferlus, while discussing the name "Viet" from historico-etymological perspective, also shows an expanded human geography view in correspondence to the concept of the cultural SEA. In his article, he says, "in the Sư ký (Shijì 史記) by Tư Mã Thiên (Simă Qian 司馬遷, 145 - 86), there appears for the first time the compound Bách Việt (Băiyuè 百越) used by the Chinese people to refer to inhabitants south of the Yangtze (Yangzi 揚子) River. These characters were used as phonetic signs to record non-Sino words; therefore, the meaning of the compound cannot be the sum of each word's meanings, i.e. bǎi (bách 百) cannot be interpreted as "trăm (ho/nước)" (one hundred (families/countries)) and yuè (việt 越) as “cái qua (dùng trong chiến tranh)" (a weapon used in battles). The term yuè (việt 越) is also found in Hanshu 漢書/汉书, the historical record of pre-Han time (206 B.C.E. - 25 C.E.), including Vu Việt (Yúyuè 於越), Lạc Việt (Luòyuè 雒越), which is currently explained as "the Viet people whose totem is the lac bird $^{1}$ (Ferlus, 2011, p.1). Ferlus'

\footnotetext{
1 The bird often seen on Vietnamese bronze drums, like this . Original French: "Les Mémoires Historiques (Shǐjì 史記) de Sīmă Qiān司馬遷 $(-145 /-86)$ nous révèlent la première attestation
} 
etymological explanation of the components of the Sino-Vietnamese phonetic cluster Lac Viẹt on the basis of analyses of its relations to other languages in south China and SEA demonstrates that in his view, SEA cannot be constrained within the current administrative limits. It is clear that, to him, the geo-cultural region of Lạc Việt, including the Vietnamese language and the culture of the Viet (Nam) people, as recorded in ancient Chinese history books, must encompass the south of China, i.e. "south of the Yangtze River" and the present Southeast Asia. When offering our additional discussion on the concept of Lac Việt (雒越) in pre-history, we did support this view of Ferlus by pointing out that several Austroasiatic languages in Southeast Asia still retain the etymological meaning of that ancient name when the Chinese used the character Lạc (Luò 雒) to phonetically record that non-Sino name (Trần Trí Dõi, 2017b).

The afore-mentioned linguistic, cultural and historical phenomena allow us to conclude that in its development, the cultural SEA has experienced perplexing changes. Thus, nonrecognition of the geographical distinction between the current SEA and the cultural SEA in the past would likely prevent us from thoroughly understanding the region's cultural and linguistic features. Subsequently, it would

des Băiyuè (băiyuè 百越), expression par laquelle les Chinois désignaient les populations au sud du fleuve Yángžr. Les caractères utilisés sont des phonogrammes qui transcrivent des vocables non chinois; la signification de l'expression Băiyuè ne peut s'expliquer par le sens propre des caractères composants, ici băi 百 “cent” et yuè 越 “hache de guerre”... Le terme yuè 越 est également consigné par plusieurs expressions dans le Livre des Han (hànshū 漢書/ 汉书) qui couvre l'histoire des Han antérieurs (-206/-25): Yúyuè 於越 "Yue principaux", Luòyuè 雒越 (sino-viet: Lạc việt) "Yue des Lạc" be difficult to fully grasp the commonalities as well as peculiarities of the Vietnamese language and culture in the panorama of this vast geographical region. In other words, clear understanding of the distinction between the administrative SEA and the cultural SEA is crucial to one's investigation of the region's cultures and languages.

\section{Indicators of Vietnam as a miniature of the cultural SEA}

\subsection{Vietnam as an agricultural geographical miniature of the cultural SEA}

As has been argued, broadly speaking, the cultural SEA enjoys the monsoon climate, borders the Pacific on the east, the Indian Ocean on the south, the Ganga in India on the west, and the Chang Jiang in the south of China on the north. Such geographical boundaries encompass several major rivers which mostly originate in the northwest and flow southward, southeastward or eastward to the sea, forming well-known deltas in terms of area, fertility and prosperity, namely the vast Huanan (South China) delta of the Chang Jiang, the Pearl River (Zhujiang) delta in China, the Red River and the Mekong River deltas (in Vietnam and Cambodia), the Chao Phraya (Menam) and the Mae Klong deltas (in central Thailand), the delta of the Irrawaddy (Ayeyarwady) and Salween (or, officially, Thanlwin) rivers (Myanmar). Owing to such a climate and rivers, the cultural SEA is endowed with special social and natural features, the most important of which is rice cultivation, and Vietnam is among those typical subregions.

Such features are perhaps the most salient of the cultural SEA. Engaged in rice farming, inhabitants normally tended their land in close communities so that they could join 
hands together to fight against natural forces and disasters. This is the natural foundation for villages to use the same type of dialects amidst the mosaic of languages in Southeast Asia. In Vietnam, this is also possibly the socio-natural reason why each village may have its own institution, so much and so strong as "village rules wipe out the king's laws", and representing such institutions is normally a typical accent or 'local tongue' for each village or region.

Agricultural inhabitants in the past had no choice other than relying on weathers for their cultivation, so they had to plan their production seasonally to accommodate changing weathers. That seasonal nature of agricultural production led to periodical or repetitive cycles of crops within certain geographical areas. Work cycles are sandwiched with pauses for relaxation and festivals. Thanks to those periodical resting times, Southeast Asian inhabitants' festivals and holidays are organized almost at the same time, and that seems to determine rice-farming or fishing-related rituals and activities in those festivals, similar to the meaning of "original" or "starting point" of the Phù Đổng (扶 董) festival in Vietnam today (Trần Trí Dõi, 2013).

Also, the geographical features of the cultural SEA reveal that periodical cultivation may have driven inhabitants to migration, and such migration was also periodical but slow. Over time, sustained and regular migration led to interwoven communities, where language and cultural contact occurred both historically and non-historically. This is exactly the reason why interwoven communities make the linguistic picture both complicated and diverse like a mosaic (Trần Trí Dõi, 2015, pp.151-191).

\subsection{Vietnam - a miniature of the cultural SEA} in terms of ethnicity
It is apparent that ethnic groups in the cultural SEA share considerable cultural features, although they may live close to one another or quite a distance apart. For instance, cultural imprints of Austronesian speakers are found scattering at various degrees all over the land south of China, along the eastern coast of Southeast Asia, particularly the islands in Southeast Asia, which means Austronesian speakers spread over a vast geographical space. This can only be attributed to sustained migration which resulted in such a large spatial diffusion of Austronesian inhabitants.

However, this is not only the case with Austronesian speakers. It is the same with other language families as well, e.g. the TaiKadai, the Miao-Yao speakers. Possibly, a typical feature of the whole cultural SEA is different communities speaking languages of different families yet sharing similar cultures though distributing over various areas. Such a phenomenon can only be explained with historico-geographical reasons. In other words, it can be asserted that the geographical, cultural and social attributes of the region have undergone complicated historical changes until their presence state.

Another conclusion can be made out of the afore-mentioned fact: the language and cultural picture of the cultural SEA has several times been re-structured and overlapped. An example is various dialects of the Vietnamese language. Even adjacent villages can speak different accents. Furthermore, not merely their pronunciation, but also their vocabulary and even grammar, differ, i.e. phonetically, lexically, and syntactically (as evident in the use of modal particles at the end of questions in some local dialects in Thanh Hoa province). Thus, it is possible to posit that even two adjacent villages may speak two different languages rather than two variants of the same language. Similar socio-cultural features 
are also found in the cultural SEA territory south of China. Such linguistic disorder and overlapping make Haudricourt, a famous linguist, admit that it is difficult to identify the origins of a number of words shared between Austronesian and Mon-Khmer languages (Haudricourt, 1966, p.33).

Also, from another perspective, it is impossible not to mention the 'intermediary' location of the cultural SEA. Geographically, the cultural SEA lies between two larger sub-continents with flourishing ancient civilizations, i.e. India and China. Naturally, these two sub-continents have exerted, and will continue to exert, significant impacts on the current cultural SEA. In one way or another, therefore, the 'intermediary' location of SEA enables it to receive various dimensions of both linguistic and cultural impacts from India and China. Examples to support this avail. Consider the distribution of ancient scripts of the Tai-Kadai speakers in the region. It is common knowledge that Tai-Kadai speakers in the south (including the Thai, the Laos, the Lư in Vietnam, Thailand and Laos PDR; the Dai in Yunnan, China, amongst others) use ancient scripts of Indian traditions while the Tai-Kadai in the north (the Zhuang in China, the Tay-Nung in Vietnam) use ancient scripts in Chinese traditions (Trần Trí Dõi, 2009, pp.271-284; 2017a, pp.46-62). Ancient scripts of the Thai in Indian traditions in southern territory belong to Khmer or Mon types as Ferlus claims (Ferlus, 1999). By contrast, in the territory east of the Red River in Yunnan Guangxi (China) and north Vietnam, ancient Tai-Kadai scripts adopt Chinese traditions, which are known as Nom characters. It is clear that the geographical 'intermediary' position of the cultural SEA is reflected in the use of ancient scripts by Tai-Kadai speakers, which deserves attention.

As analyzed, from geographical, sociocultural perspectives, it is obvious that the cultural SEA has been inhabited by not only indigenous people but also migrants who speak languages of different families. Along with population mix, the region finds itself at the crossroad of two neighboring developed civilizations. Such socio-cultural circumstances have exerted their impacts on the languages and cultures of the cultural SEA, including the Vietnamese language and culture.

\subsection{Shared SEA cultural features in Vietnam}

To illustrate that Vietnam is a miniature of the cultural SEA, we will not provide all specific details but merely identify a few fundamental ones. In our view, these can be regarded as typical cultural invariants, or constants, known to humanity scholars. Following are some examples.

\subsubsection{Tangible cultural invariants}

On the basis of common agricultural civilization, SEA inhabitants in different subregions have created relatively uniformed ethnic cultures. Yet, apart from that uniformity, each locality presents its own peculiarities that make them diverse. Some tangible cultural constants found in Vietnam include:

First, rice cultivation, which I believe is the most salient feature of the cultural SEA. Inhabitants in this area live mostly on rice, which is cultivated on wet paddy fields and dry hill slopes. Buffaloes and oxen are domesticated as draft animals; similar tools are used; and irrigation systems work on the principle of gravity. Thus, suitable ecological 
environments for the cultural subregions that emerge are deltas, mountain valleys, and hill slopes. Also, part of the cultural SEA inhabitants are skillful on waters, i.e. in fishing and processing aqua-products in rivers, lakes, lagoons, coastal as well as offshore fishing grounds. Vietnam is rich in such cultural constants.

Along with rice cultivation and fishing, various handicrafts flourish, including textile and dyeing (silk, cotton, fibers from banana, pineapple, coconut, etc.), hand knitting, ceramics, lacquer, wood carving, jewelry, to name just a few. In other words, sophisticated handicrafts formulate another cultural constant of the inhabitants in the cultural SEA, including Vietnam.

Finally, stilt houses. Broadly speaking, the whole area tends to maintain the tradition of living in houses on stilts. Yet, there are a variety of types of stilt houses: those on slopes differ from those on flat land; those in dry land differ from those in swamps or wetlands; long stilt houses apparently differ from shorter ones. Living customs in different types of stilt houses also differ from one group to another, despite e pluribus unum - unity in diversity, e.g. the decoration of the rooftop all over Southeast Asia. Stilt houses are still preserved intact in Vietnam.

\subsubsection{Intangible cultural commonalities}

Amidst cultural diversity of various ethnic groups or states in the cultural SEA, shared intangible cultural features are fully present in Vietnam, including:

Language: communities in the cultural SEA are found to speak 5 different language families, namely Austroasiatic, Austronesian, Tai-Kadai, Miao-Yao, and Sino-Tibetan. Ethnic groups in different parts of Vietnam are also speaking languages of these 5 families (Trần Trí Dõi, 2015), which is also the case in Laos PDR, Thailand or Malaysia. Nevertheless, among those families, Austroasiatic is considered native of SEA in pre-history, although there remains controversy over its original geographical distribution. The fact that Austroasiatic speakers diffuse all over the cultural SEA demonstrates that this family is native in pre-history, and in Vietnam, Austroasiatic speakers also stretch along the country from north to south with the largest number of ethnic groups as well as individual speakers.

Next, folk culture and beliefs. The cultural SEA is rich with a variety of folk performances (e.g. water puppetry, dances with masks), and traditional music (with diverse instruments made of natural materials). This is also the region where family values and respect to the elderly $\&$ ancestors are appreciated, and festivals reflecting strong community and solidarity spirits among villages and ethnic groups are celebrated. It is common to witness those folk culture and beliefs respectfully preserved in the country. Examples include gong music of the Muong in the north or other ethnic groups in the Central Highlands, fish worshipping rituals and festivals in almost every village along the coast from north to south, village festivals in commemoration of their founding fathers or water sources such as Phù Đổng festival, Đền Hùng (Hung Temple) festival, buffalo-slaughtering festivals in the Central Highlands, amongst others. Thanks to such festivals, communities remain close-knit, and strong solidarity is maintained among individual villagers as well as different ethnic groups.

In the folk culture and beliefs in the 
cultural SEA, women's role is socially recognized and respected. Vietnam enjoys a diversity of maternity worshipping beliefs and practices everywhere. In the north, there is a temple worshipping Mother Âu Cơ (Mother of the Nation) in Phu Tho, temples worshipping the Trung Sisters in Hanoi and other places, or Goddess Liễu Hạnh temples in Hanoi, Nam Dinh, and Thanh Hoa. In the central part of the country are Hon Chen temple in Hue, Po Naga tower worshipping Goddess Ana of the Cham people in Khanh Hoa, and in the south are Ba Den Mountain in Tay Ninh and Goddess Sam Mountain in An Giang. These are holy places where meritorious women or goddesses are glorified and celebrated among the folks.

Religions are another indicator of Vietnam as a miniature of the cultural SEA. On the basis of such native folk beliefs as animism, agricultural rituals as Phù Đổng festival, ancestralism as Hung Temple festival, Vietnam adopted, inter alia, Hinduism, Buddhism, Islam, Christianity, Taoism, like other states in the cultural SEA. This adds to the diversity and richness of the spiritual life of Vietnamese communities without complicating their daily life.

2.3.3. "Receiving" culture, or culture of adoption

In Southeast Asia there has been a long process of receiving cultural influences from the south (from India or the Arabic world), from the north (China or Japan), and from Europe, which substantially increases its cultural and religious diversity. This is also the case in Vietnam. Though sharing those regional features, Vietnam retains its own attributes for its national identity amidst the mosaic of the region. Archeological studies reveal that the Dong Son (東山,
Dongsan) civilization, which existed in North Vietnam from the first millennium B.C.E. to the second century C.E. (Hà Văn Tấn 1997, pp.759 - 760), witnessed the highest flourishment at equal pace of the cultures of ethnic groups in SEA. In that era, SEA culture remained non-Chinese and nonIndian. Later, ethnic cultures in this region gradually received influences from the two neighboring civilizations of India and China. Since the $2^{\text {nd }}$ century C.E., these two civilizations exerted continuous influence on SEA for centuries, which altered the Dong Son culture so much that upon their arrival on this land, Europeans had to use the name Indochina/Indochine to call it.

It is known that Chinese civilization penetrated Southeast Asia from the basin south of the Yellow River, crossing the vast basin of the Chang Jiang to the Red River Delta in Vietnam. Such penetration was made through wars, together with the predominant “popularization' of the Chinese writing system, culture, socio-political and legal institutions, amongst others, to territories ruled by the Chinese. However, thanks to the sustainability of previous indigenous culture, and the vast social space of Dong Son Culture in SEA, such Chinese penetration seemed to have "stopped" at the territory of the Viet people in the Red River Delta. This is possibly the cultural reason why, after a thousand years under the rule of several Northern feudal dynasties, Vietnam managed to separate from such a rule, which was a mission impossible to the Zhuang neighbors in southern China.

While Chinese civilization's penetration into SEA occurred in a rolling manner, the penetration of Indian civilization took place through the construction of "cultural 
centers" or "cultural islands" with significant attraction to their vicinity. In other words, penetration from the north to SEA was made through territorial conquers for the purpose of "cultural diffusion" while that from the south was through the construction of factories and trade points along SEA coasts and islands which became Indian-style commercial zones with considerable influence on the cultural SEA. This is possibly the reason why the Thai community (in Thailand) and the Zhuang people in China demonstrate different responses to Buddhism.

Possibly, through a thousand years of Indianization and Sinization in such different manners, subregions in SEA bear various cultural imprints. While indigenous cultures in SEA subregions are still preserved, the northeastern part of the cultural SEA bears clearer Chinese cultural influences whereas Indian cultural traits are more visible in the southern part of the cultural SEA. Later, indigenous cultures in SEA were also subjected to Arabic and Western cultural impacts to various degrees. Amidst such differences among subregions of the cultural SEA, the subregion of Dong Son Culture, with its center being the Red River Delta in Vietnam, seems to be the boundary between the southern and northeastern parts of the cultural SEA.

\section{Vietnam's treatment to cultural and linguistic borrowings}

Thus, like other states in the cultural SEA, in its history, Vietnam has never lost its indigenous culture, thanks to which it could receive cultural influences from outside to make its own culture richer. Interesting evidence can be found in language - an arbitrary social phenomenon.

\subsection{Indigenousness in Vietnamese language and culture}

In order to understand Vietnam's selective choices of foreign cultural influence to enrich its own, it is important to realize the indigenousness of Vietnamese language and culture. Upon setting foot in the cultural SEA, it was natural that the first Europeans instantly felt Indian and Chinese cultures here. Nevertheless, when they could secure access to the cultural foundation of the region, especially its agricultural civilization, they realized its cultural indigenousness, which is reflected in several linguistic and cultural features of the region, including Vietnam. Hereafter are a few examples.

For instance, superstructurally, the North of Vietnam clearly features Indian or Chinese cultural influences, as shown in village institutions with Chinese Confucian hierarchy along with the presence of Indianoriginated Buddhism. At a broader scale, however, such foreign influence is subject to indigenous cultural control. Despite very strong Confucian impacts, the petite peasant foundation of villages in North Vietnam did affect superstructural institutions of the feudal society. Owing to such multidimensional impacts, there remained different strongly Confucian customs and practices in Vietnamese villages. In other words, the petite peasant society did not allow the monopoly of Confucianism in their village institutions ${ }^{2}$. That is the reason why various Vietnamese feudal dynasties on the one hand appreciated Confucian examinations and appointments, and respected the harmony of Buddhism, Taoism and Confucianism together with other folk beliefs on the other

Perhaps this is the reason why the Vietnamese have the proverb "Village rules wipe out the King's laws". 
hand. Vietnamese Confucianism has been proved different from that in the North where it originated (Nguyễn Kim Sơn, 2012). It is not a coincidence that in the $10^{\text {th }}$ century, when Vietnam gained its independence from Chinese feudal forces, amidst the then flourishment of Chinese culture which was learned by the people of Dai Viet, King Ly Cong Uan continued to take Buddhism as the national religion. Such a choice was partly governed by Vietnamese indigenous culture, and partly demonstrated the Ly's awareness of the counterweight of Indian culture to Chinese feudal culture. ${ }^{3}$

Linguistically, the SEA indigenousness of the Vietnamese language is clear. Historically, there is sufficient evidence in phonetic rules for linguists to confirm that Vietnamese is among indigenous Austroasiatic languages (Trần Trí Dõi, 2011). The Austroasiatic origin of Vietnamese allowed it to borrow a large number of words from other cultures, including Indian, Chinese and Western, so as to enrich itself. This is one of many reasons why researchers of Vietnamese proposed different ideas on the origin of the language in the cultural SEA.

It is very likely that thanks to the strong preservation of the SEA cultural foundation, Vietnam, especially during the Nguyen Dynasty, chose a development model pretty similar to the northern social institutions, which is different from the rest of SEA, yet such a choice could not prevent Vietnam from returning to its integration with SEA. The choice of development models for a state tends to be controlled by particular historical circumstances, but basically, it is the cultural background (i.e. the indigenous

3 Compared to the choice of national religion in such neighboring countries as Laos PDR, Cambodia and Thailand. culture) of that state that determines its longterm development trend. By this we mean, culturally, Vietnam could only develop amidst the context of the cultural SEA.

\subsection{Linguistic borrowing}

The indigenousness of the cultures and languages of SEA as well as Vietnam is also related to the ability to receive and borrow, i.e. SEA languages and cultures, including Vietnamese, are both borrowers and lenders. As lenders, SEA languages and cultures affect those in adjacent territories whereas as borrowers, SEA languages and cultures are subject to impacts from neighboring languages and cultures. In other words, reception and borrowing occurred both ways.

Examples could be words possibly borrowed from Austroasiatic languages in the Chinese lexicon. In an article on the proper name of Cao Lỗ (泉魯), we found that the name was given to a general under the reign of King An Duong of the Kingdom of Au Lac (B.C.E.) at a much later time, around the $13^{\text {th }}$ $15^{\text {th }}$ centuries. This means that the name Cao Lỗ (泉魯) in Vietnamese history is a purely Sino-Vietnamese word to refer to Thần Nỗ, which is the Sino-Vietnamese pronunciation of the Chinese 神㛎.

Along with this Sino-Vietnamese name are other forms in Vietnamese that are still preserved, e.g. Thần Ná/Thần Nỏ (all of which mean the God of the Bow). Among those non-Sino-Vietnamese variants that remain in Vietnamese, Ná is still used among various languages of the Mon-Khmer branch of Austroasiatic family. Ná is re-constructed by Sidwell as the phonetic form $/ *_{\text {snaa/ in Proto }}$ West Bahnar group, as /*sənhaa/ in Proto Katu, and $/ \mathrm{hna}^{\mathrm{cl} /}$ in Proto Southwest Thai of the Tai-Kadai group (Sidwell, 2003, p.65). This historical phonetic evidence leads to the position that "the object" that the Chinese language 
borrowed and recorded as the character 驽 (Beijing pronunciation nŭ, Sino-Vietnamese pronunciation nố, re-constructed by Baxter \& Sagart (2014) as *C.n'a?-B) could possibly originate from the south, i.e. from languages of the Mon-Khmer branch of Austroasiatic family, which is the ancestor of the Vietnamese language. This is to say ná in Vietnamese and $n \tilde{\hat{o}}$ in Chinese may have shared the same origin. If so, originally, it was an Austroasiatic word before being borrowed into Chinese and written using a Chinese character. Subsequently, it was re-borrowed into Vietnamese, an Austroasiatic language. When it was re-borrowed, its Early Sino-Vietnamese phonetic form was nỏ, and later, it became the Sino-Vietnamese phonetic form of nỗ (Trần Trí Dõi, 2013a). This also means SEA languages and cultures are both lenders and borrowers.

Borrowings from Austroasiatic languages in Chinese can also be seen in the etymology of the concept of Lac Viẹt (雒越) still in current use in Vietnam and China (Trần Trí Dõi, 2017b). It is likely that ancient Chinese used as many as 3 Sino characters 雒/駱/絡, which are all currently pronounced as "Lạc" in SinoVietnamese and "luò" in Beijing vernacular of the Chinese language, to refer to the non-Sino inhabitants south of the Yangtze River. These were the phonetic records of the Austroasiatic name of the land or its people. Reconstruction of Old Chinese by such linguists as Schuessler (2007) and Baxter \& Sagart (2014) provides the semantic values of these words. It is highly possible that these Chinese characters which represent such an Austroasiatic word were used to refer to the particular inhabitants whose nomenclature remains in various SEA languages (Ferlus, 2011).

That the cultures and languages in SEA are borrowers can be more visible. For instance, the Sino-Vietnamese pronunciation of Chinese characters in the Vietnamese language analyzed by Nguyễn Tài Cẩn (1979) is a typical example of such borrowings. This can be explained in different ways, including the complete and sophisticated writing system - the most salient and crucial feature of the Chinese language, thanks to which Chinese customs, socio-political and legal institutions, inter alia, could be borrowed into the languages and cultures of various SEA states. Chinese characters were also borrowed by different ethnic groups in the cultural SEA such as the Zhuang, Tay, Nung, Yao, Viet to make their own writing systems (e.g. the Nom characters), which is another convincing evidence of the cultures and languages in Southeast Asia as borrowers.

To provide more evidence of borrowings from Chinese in several languages of the cultural SEA, we hereby present examples found in both the Tay and Viet languages in Vietnam. Words denoting "parts of the human body" borrowed from Chinese in Tay-Nung language demonstrate special treatment, which reflects the intermediary geographical location of the Tay-Nung speakers. A list of such basic words in Tay-Nung in comparison with Vietnamese, Tai Yo and Sino can be made as seen hereafter ${ }^{4}$ :

\footnotetext{
4 Tay-Nung examples are taken from: (i) Hoàng Văn Ma - Lục Văn Pảo (2003). Viet-Tay-Nung Dictionary, $2^{\text {nd }}$ edition (revised). Encyclopedia Publishing House. Hereafter referred to as HVM-LVP Dictionary for short; (ii) Vương Toàn - Hoàng Triều Ân (2016). Tay-Viet Dictionary. National Culture Publishing House. Hereafter referred to as VT-HTA Dictionary; (iii) Bac Kan Provincial People's Committee (2010). Slon tiengr Tày (Learning the Tay language). Internal publication. Hereafter referred to as Bac Kan Lexicon. Thai examples are taken from Tai Yo Vocabulary provided by Sầm Công Danh, an individual of the Tai Yo group in Quy Chau. Meanwhile, Proto Tai-Kadai examples are cited from $\mathrm{Li}$ (1977).
} 


\begin{tabular}{|c|c|c|c|c|c|c|c|c|c|}
\hline \multicolumn{2}{|c|}{ Vietnamese } & \multicolumn{3}{|c|}{ Tay-Nung } & \multicolumn{2}{|c|}{ Thai } & \multicolumn{2}{|c|}{ Chinese } & \multirow[t]{2}{*}{ English } \\
\hline $\begin{array}{c}\text { Quoc ngu } \\
\text { (current } \\
\text { Romanized } \\
\text { writing system } \\
\text { of Vietnamese) }\end{array}$ & Sound & $\begin{array}{c}\text { VT-HTA } \\
\text { Dictionary }\end{array}$ & $\begin{array}{l}\text { HVM-LVP } \\
\text { Dictionary }\end{array}$ & $\begin{array}{c}\text { Bac Kan } \\
\text { Lexicon }\end{array}$ & $\begin{array}{c}\text { Tai Yo } \\
\text { Vocabulary }\end{array}$ & $\begin{array}{l}\text { Proto Tai- } \\
\text { Kadai } \\
\text { (Li) }\end{array}$ & $\begin{array}{l}\text { Chinese } \\
\text { character }\end{array}$ & $\begin{array}{c}\text { Beijing } \\
\text { pronun- } \\
\text { ciation }\end{array}$ & \\
\hline $\begin{array}{l}\text { đầu, } \\
\text { trốc }\end{array}$ & $\begin{array}{l}\text { dəw } \\
\text { tok }^{35}\end{array}$ & $\begin{array}{c}\text { hua/thua } \\
\text { bẩu }\end{array}$ & $\begin{array}{l}\text { hua } \\
\text { bẩu }\end{array}$ & $\begin{array}{l}\text { hua }^{5} \\
\text { bẩu }\end{array}$ & huə ${ }^{13}$ & ${ }^{*}$ hua $_{\mathrm{A} 1}$ & 头, 頭 & tóu & head \\
\hline tóc & $\mathrm{tok}^{35}$ & phiôm & phjôm & phjôm & $\mathrm{p}^{\mathrm{h}} \mathrm{om}^{13}$ & $* \mathrm{p}^{\mathrm{h}} \mathrm{Om}_{\mathrm{A} 1}$ & 发 & fà & hair \\
\hline mặt & $m a ̆ t^{32}$ & nả & nả & nả & na: ${ }^{33}$ & ${ }^{*}$ na: ${ }_{\mathrm{C} 1}$ & $\begin{array}{l}\text { 脸、 } \\
\text { 面 }\end{array}$ & $\begin{array}{l}\text { liăn } \\
\text { miàn }\end{array}$ & face \\
\hline mắt & $\mathrm{măt}^{35}$ & tha/ha & tha & tha & $\mathrm{ta}^{: 33}$ & $*_{\mathrm{ta}}{ }_{\mathrm{A} 1}$ & 眼 & yăn & eye \\
\hline mũi & $m u j^{324}$ & đăng & đăng & đăng & $\operatorname{dan}^{13}$ & $* \mathrm{da \eta}_{\mathrm{A} 1}$ & 鼻 & bí & nose \\
\hline tai & $\mathrm{taj}^{33}$ & $\mathrm{xu}$ & $\mathrm{xu}$ & $\mathrm{xu}$ & hu: $:^{13}$ & $*_{\mathrm{hu}} \mathrm{A}_{\mathrm{A}}$ & 耳 & ěr & ear \\
\hline răng & 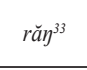 & khẻo & khẻo & khẻo & $\mathrm{h} \varepsilon: \mathrm{w}^{33}$ & ${ }^{*} \mathrm{k}^{\mathrm{h}}$ iaw $_{\mathrm{C} 1}$ & 牙、齿 & $\begin{array}{l}\text { yá } \\
\text { chǐ }\end{array}$ & tooth \\
\hline lưỡi & lurrj $^{324}$ & $\operatorname{lịn}$ & $\operatorname{lin}$ & $\operatorname{lịn}$ & $\operatorname{lin}^{53}$ & ${ }^{*} \operatorname{lin}_{\mathrm{C} 2}$ & 舌 & shé & tongue \\
\hline tay & tăj $^{33}$ & mừ/ & mừ & mừ & mu: ${ }^{55}$ & $* \mathrm{mi}_{\mathrm{A} 2}$ & 手 & shǒu & arm \\
\hline chân & cân $^{33}$ & kha & kha & kha & ha: $:^{13}$ & ${ }^{*} \mathrm{k}^{\mathrm{h}} \mathrm{a}:{ }_{\mathrm{A} 1}$ & 脚 & jiăo & leg \\
\hline
\end{tabular}

${ }^{1}$ The table shows that different forms of [hua $\left.{ }^{33}\right],\left[\mathrm{t}^{\mathrm{h}} \mathrm{ua}^{33}\right]$ and [bâw $\left.{ }^{21}\right]$ are preserved in Tay-Nung to refer to the head whereas most other words exist in single forms, which are consistent across Tay-Nung, Tai Yo and reconstructed Proto Tai-Kadai by Li Fang Kuei (Lý Phương Quế). Such correspondence in Tay-Nung itself and among Tay-Nung, Tai Yo and reconstructed Proto Tai-Kadai seems to assert that the phonetic form $\left[\mathrm{hua}^{33}\right]$, and possibly even the variant $\left[\mathrm{t}^{\mathrm{h}} \mathrm{ua}^{33}\right]$, are pure Tai-Kadai, i.e. a descendant of the original whereas [bâw ${ }^{21}$ is very likely to be a borrowing rather than pure Tai-Kadai, as seen in the case of $\left[\right.$ hua $\left.^{33}\right]$.

It seems that Tay-Nung has similar cases of borrowing to the words denoting the head in Vietnamese. Currently, Vietnamese has parallel forms of $\left[\mathrm{tok}^{35}\right]$ (written as trốc in quoc $n g u)$ in some localities and [ $\left.\mathrm{d \partial w}^{21}\right]$ (written as đầu in quoc $n g u$ ) in popular Vietnamese, in which the local $\left[\mathrm{tok}^{35}\right]$ is believed to be the original Austroasiatic in

5 During his field trip in Bac Kan in 2017, the Japanese doctoral candidate Ayaka Sannuij (Osaka University) also reported that the local Tay-Nung dialect in Bac Kan had the word đầu pronounced as the sound written as thua in quoc ngu.
Vietnamese (Trần Trí Dõi, 2011, pp.79-81) whereas the popular $\left[\mathrm{d \partial w}^{21}\right]$ is identified by researchers as the borrowed form of the Chinese 頭 [tóu] in the period of Archaic Viet-Muong AVM) (Trần Trí Dõi, 2011, p.141). As reconstructed by Baxter \& Sagart (2014, p. 363), this Sino-originated word had its Old Chinese (OC) form of $\left[{ }^{*} m-t^{\uparrow} o\right]$ and Middle Chinese (MC) form of [*duw-D $]^{6}$, which was borrowed into Vietnamese and called Sino-Vietnamese by Wang Li (王力, Vương Lực) (1948) and other Vietnamese scholars. The MC form [*duw-D] with the entering tone $\mathrm{D}$ reconstructed by the two scholars seems to prove that the currently popular Vietnamese form of $\left[\mathrm{d \partial w}^{21}\right]$ was actually borrowed in the MC period, similar to a whole class of Sino-Vietnamese words thanks to the contact between Vietnamese and $\mathrm{MC}$.

Let us go back to the case of parallel forms of the words denoting the head in Tay Nung. As the phonetic form [hua ${ }^{33}$ ] and the variant $\left[\mathrm{t}^{\mathrm{h}} \mathrm{ua}^{33}\right]$ are regarded as pure Tai-Kadai, it is

\footnotetext{
6 In W.H. Baxter \& L. Sagart (2014), MC tones are symbolized as A (bình, even), B (thuợng, rising), C (khú, departing) and D (nhập, entering). We use the same symbols in this paper when citing MC examples.
} 
highly likely that the phonetic form [bâw $\left.{ }^{21}\right]$ was borrowed. The comparison of the Sinooriginated word [ $\left[\mathrm{w}^{21}\right]$ ("đầu") analyzed above and the form [tóu] (頭/头) as well as other words denoting parts of the body in current Chinese reveals that the phonetic form [bâw $\left.{ }^{21}\right]$ in Tay-Nung was possibly borrowed from Chinese. Also, the comparison of the OC form $\left[{ }^{*} \mathrm{~m}-\mathrm{t}^{\dagger} \mathrm{o}\right]$ and the MC [*duw-D] can also lead to a possible conclusion that the form [bâw ${ }^{21}$ ] was borrowed into Tay-Nung from Chinese in the late OC period or in the early MC period.

The reason why we could come to such conclusions is the correspondence between the rhyme and initial consonant in Tay-Nung and the OC \& MC forms reconstructed by Baxter and Sagart. Specifically, the rhyme $\left[\hat{a} w^{21}\right]$ in [bâw ${ }^{21}$ in Tay-Nung possibly corresponds to the rhyme [*uw] in $\mathrm{MC}$, similar to the

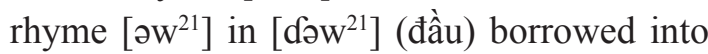
Vietnamese in AVM period. The problem is the initial consonant [b] (voiced bilabial plosive) in Tay-Nung which finds no correspondence at all to both the initial consonants in the reconstructed OC $\left[{ }^{*} \mathrm{~m}-\mathrm{t}^{\uparrow}\right]$ and $\mathrm{MC}\left[{ }^{*} \mathrm{~d}\right]$. However, the OC form $\left[{ }^{*} \mathrm{~m}-\mathrm{t}^{\mathrm{c}}\right]$ reconstructed by Baxter and Sagart provides an indirect indication that in OC, the Chinese word [tóu] (头) could have been sesquisyllabic with the initial consonant cluster being a pre-syllabic element [*m-] (bilabial) combined with the consonant $\left[-\mathrm{t}^{\mathrm{c}}\right]$. It is possible that this presyllabic bilabial element [*m-] resulted in the initial consonant $[\mathrm{b}]$ in [bâw $\left.{ }^{21}\right]$ in current Tay-Nung when it was borrowed from the OC $\left[{ }^{*} \mathrm{~m}-\mathrm{t}^{\varsigma} \mathrm{o}\right]$ and monosyllabized.

The monosyllabization of sesquisyllabic words shown above is a process of change found in several Viet-Muong languages, a group that includes Vietnamese (Trần Trí Dõi, 2011a, pp.322-343). Vietnamese borrowed $\left[\mathrm{d} \partial \mathrm{w}^{21}\right]$ from Chinese while retaining $\left[\mathrm{tok}^{35}\right]$ in several dialects. Furthermore, in current Vietnamese, some cases make use of the same Early Sino-Vietnamese treatment as [bâw $\left.{ }^{21}\right]$ in Tay-Nung. For instance, the initial consonant [b] (as in bến - wharf) corresponds to the Sino-Vietnamese initial consonant [t] (as in 津 tân - new) whose reconstructed forms in both OC $(* \operatorname{tsin}\{*[\mathrm{ts}] \mathrm{i}[\mathrm{n}]\})$ and MC (*tsin-A) were an initial consonant which was either bilabial or dental. The Sino-originated syllable bì in phân bì (compare) has the Early Sino-Vietnamese initial consonant [b] corresponding to the Sino-Vietnamese initial consonant $[\mathrm{t}]$ in 比 (ty - compare) which was (*C.pij?) in OC and (*pjijX-B) in MC, and this is not unusual in Vietnamese. Thus, it is also possible that the initial consonant [b] in [bâw ${ }^{21}$ in Tay-Nung which was borrowed from Chinese corresponds to the Chinese initial consonant $[\mathrm{t}]$.

Thus, it is possible for us to infer that the word [bâw $\left.{ }^{21}\right]$ in Tay-Nung was borrowed from the Chinese 頭 [tóu] at the time when the ESV (Early Sino-Vietnamese) word class was formed in Vietnamese. Although they borrowed the same Chinese words from the basic group of words denoting parts of the human body, Tay-Nung and Vietnamese languages differ in their treatment of the initial consonant $[\mathrm{b}]$ and [d] in Tay-Nung and Vietnamese respectively, which means the borrowed form [bâw $\left.{ }^{21}\right]$ in Tay-Nung is closer to the OC $\left[{ }^{*} m-t^{\varsigma} o\right]$. Considering the geographical residence of prehistoric inhabitants in the cultural SEA, it is clear that Chinese had earlier contact with TaiKadai communities in the north than speakers of Vietnamese, a language in the Austroasiatic family in the south.

\section{Conclusion}

Vietnam is a country in the cultural SEA, and is considered a miniature of the region's 
cultures and languages. Evidence for this can be found in the cultural and linguistic features in Vietnam which are representative of different states in SEA. Most typical is the rice-cultivating culture that is reflected in various dimensions of material and spiritual culture, and such reflection also varies from subregion to subregion in the whole region.

However, owing to its special geographical location, Vietnam marks the boundary of cultural and linguistic distinctions among different subregions, as seen in current linguistic and cultural phenomena in the country. In other words, Vietnam can be regarded as an intermediary hub for linguistic and cultural interchange between the north and the south of the Asian continent. Also, it retains its indigenousness while serving as the gateway for the north-south contact among East Asia, Southeast Asia and South Asia.

\section{References}

\section{Vietnamese}

Đào Duy Anh (1997). Đất nước Việt Nam qua các đời (Vietnam through Ages). Huế: Thuận Hóa Publishing House.

Bellwood P. (2005). Nhũng nhà nông đầu tiên - Nguồn gốc của các xã hội nông nghiệp (First peasants Origin of agricultural societies). Hanoi: Thế giới Publishing House (translated by Tạ Đức - Nguyên Việt).

Nguyễn Tài Cẩn (1979). Nguồn gốc và quá trình hình thành cách đọc Hán Việt (Origin and process of formulating the Sino-Vietnamese pronunciation). Hanoi: Social Sciences Publishing House. Republished by VNU Press, 2000.

Nguyễn Tài Cẩn (1995). Giáo trình lịch sủ ngũ âm tiếng Việt (So thảo) (Vietnamese Historical Phonetics - A course book) (Preliminary version). Hanoi: Education Publishing House.

Trình Năng Chung (2014). Ảnh hưởng của văn hóa Đông Sơn ở vùng Lưỡng Quảng, Trung Quốc (Dong Son Culture's influence in Liangguang, China), trong Giao luu văn hóa góp phần tăng cuờng nền tảng quan hệ Việt Nam - Trung Quốc (in Cultural interchange for strengthened Vietnam-China relation). Hanoi: Hồng Đức Publishing House, pp. 201-215.

Trần Trí Dõi (2005). Giáo trình Lịch sư tiếng Việt (so tháo) (History of the Vietnamese Language) (preliminary version). Hà Nội: Nxb Đại học Quốc gia Hà Nội (VNU Press). Re-published 2007.

Trần Trí Dõi (2009). Sơ bộ nhận xét về tình hình phân bố chữ cổ truyền thống của một vài ngôn ngữ Thái-Kađai ở Việt Nam (Preliminary comments on the distribution of traditional scripts of Tai-Kadai languages in Vietnam). The First International Symposium on Kam - Tai languages in Guangxi University for Minorities, 18-19 December 2008; in Địa danh và nhũng vấn đề lịch sứ - văn hoá của các dân tộc nhóm ngôn ngũ Tày - Thái Việt Nam (Geographical names and historicocultural issues of ethnic speakers of Tay-Thai language group in Vietnam). Hanoi: Thế giới Publishing House, pp. 271-284.

Trần Trí Dõi (2011). Giáo trình lịch sủ tiếng Việt (History of the Vietnamese Language). Hà Nội: Nxb Giáo dục Việt Nam.

Trần Trí Dõi (2011a). Một vài vấn đề nghiên cúu so sánh-lịch sử nhóm ngôn ngũ Việt-Mường (Issues in historico-comparative research on Viet-Muong language group). Hà Nội: Nxb Đại học Quốc gia Hà Nội (VNU Press).

Trần Trí Dõi (2012). Họ ngôn ngữ và văn hóa tiền sử: Trường hợp văn hóa Đông Sơn và họ Thái - Kađai (Language families and prehistoric culture: the case of Dong Son culture and Tai-Kadai language family), in Cộng đồng các tộc người ngũ hệ Thái-Kađai ở Việt Nam (Tai-Kadai speaker communities in Vietnam). Hanoi: Thế giới Publishing House, pp. 337-346.

Trần Trí Dõi (2013). Tên gọi thánh "Dóng" và lễ hội "Phù Đổng": góc nhìn từ ngữ âm lịch sử tiếng Việt (The names of God Dong and Phu Dong Festival: from the perspective of Vietnamese historical phonetics). Hội thảo Việt Nam học lần thứ IV Việt Nam trên đường hội nhập và phát triển bền vũng (the $4^{\text {th }}$ international conference on Vietnamese Studies: Vietnam on the way to integration and sustainable development), Hanoi, 26-28 November 2012, re-published in Linguistics, 2(285), pp.3-10.

Trần Trí Dõi (2013a). Tên Hán Việt của tướng Cao Lỗ 皇 魯 thời Âu Lạc - An Dương Vương: từ góc nhìn ngữ âm lịch sử tiếng Việt (The Sino-Vietnamese name of General Cao Lỗ 泉魯 under the reign of King An Duong in Au Lac). Hội thảo quốc tế Nghiên cúu giảng dạy ngôn ngũu, văn hóa Việt Nam - Trung Quốc lần thứ IV (the $4^{\text {th }}$ international conference on Research and teaching Vietnamese and Chinese languages and cultures), ĐHKHXH\&NV-ĐHQGHN (USSH-VNU), 14 December 2013. Hà Nội: Nxb Đại học Quốc gia Hà Nội (VNU Press), pp. 87 - 95.

Trần Trí Dõi (2015). Các ho ngôn ngũ ở Việt Nam (Language Families in Vietnam). Hanoi: VNU Press.

Trần Trí Dõi (2017). Trao đổi về vị trí của cư dân nói ngôn ngữ Thái - Kadai trong lịch sử Việt Nam thời tiền sử (On the position of Tai-Kadai speakers in Vietnam prehistory). Trong Phát huy vai trò, bản 
sắc cộng đồng các dân tộc Thái - Kadai trong hội nhập và phát triển bền vĩng (in Developing the roles and identities of Tai-Kadai ethnic communities in the integration and sustainable development context) (Hội nghị quốc gia về Thái học lần thứ VIII, Nghệ An, 25 tháng 6 năm 2017 - the $3^{\text {rd }}$ national conference on Thai Studies in Nghe An, 25 June 2017). Hà Nội: Thế giới Publishing House, pp. 46-62.

Trần Trí Dõi (2017a). Tiếp tục thảo luận về bài viết "Những từ Thái và vị trí của người Thái trong lịch sử Việt Nam" của L.Kelley (Further discussion on "Tai Words and the Place of the Tai in the Vietnamese Past" by Liam Kelly"). Linguistics, 3(334), pp.3-14.

Trần Trí Dõi (2017b). Trao đổi thêm về từ nguyên của yếu tố "lạc (luò 雒/駱)" trong tổ hợp "lạc việt (luòyuè 雒越)” (Further discussion on the etymology of "lạc (luò 雒/駱)" in the compound "lạc việt (luòyuè 雒 越)". Museum and Anthropology, 2(18), pp. 41-53.

Haudricourt, A.G. (1966). Giới hạn và nối kết của ngôn ngữ Nam Á ở Đông Bắc (Boundaries and connection among Austroasiatic languages in the Northeast), Linguistics, 1(1991), pp. 32 - 40.

Vũ Quỳnh - Kiều Phú (thế kỷ XV). Lĩnh Nam chích quái. Đinh Gia Khánh dịch, Hà Nội: Nxb Văn hóa, 1960.

Nguyễn Kim Sơn (chủ biên) (ed.) (2012). Kinh điển Nho gia tại Việt Nam (Confucian classics in Vietnam). Hà Nội: Nxb Đại học Quốc gia Hà Nội.

Hà Văn Tấn (1981). Giao lưu văn hoá ở người Việt cổ(Cultural interchange among ancient Vietnamese people). In Văn hoá hoc đại curong và co sở văn hoá Việt Nam (General Cultural Studies and Vietnamese Cultural Foundation). Hà Nội: Nxb Khoa học xã hội, tr. 163 - 191.

Hà Văn Tấn (1997). Theo dấu các văn hóa cổ (Tracing ancient cultures). Hà Nội: Nxb Khoa học xã hội.

Trần Quốc Vượng (1970). Từ truyền thuyết, ngữ ngôn đến lịch sử (From legends and language to history). Trong Hùng Vurong dưng nước (The Making of the Nation by Kings Hung), tập I, Hà Nội: Nxb Khoa học xã hội, tr. 148-155.

Lý Tế Xuyên (1329). Việt điện u linh. Đinh Gia Khánh dịch, Hà Nội: Nxb Văn học, 2001.

\section{English}

Alves, M. J. (2016). Identifying Early SinoVietnamese Vocabulary via Linguistic, Historical, Archaeological, and Ethnological Data. Bulletin of Chinese Linguistics 9, 264-295.
Baxter, W.H. \& Sagart L. (2014). Old Chinese: a new reconstruction. Oxford: Oxford University Press.

Ferlus M. (2008). Etymology of *wat/yuè (越) “people, principality" (as in Băiyuè 百越). The 41 $1^{\text {st }}$ ICSTLL, 17-21 September 2008 - SOAS, University of London.

Kelley, L. (2013). Tai Words and the Place of the Tai in the Vietnamese Past. Journal of the Siam Society, 101(2013), 55-84.

Li Fang Kuei (1977). A Handbook of Comparative Tai. Honolulu: University of Hawaii Press.

Phan, J. D. (2012). Mường is not a subgroup: Phonological evidence for a paraphyletic taxon in the Viet-Muong sub-family. Mon-Khmer Studies, 40, 1-18.

Schuessler, A. (2007). ABC Etymological Dictionary of Old Chinese. Honolulu: University of Hawaii Press.

Sidwell, P. (2003). A handbook of comparative Bahnaric. Canberra: The Australian National University.

Sidwell, P. (2010). The Austroasiatic central riverine hypothesis. Journal of Language Relationship, 4(2010), pp. 117-134.

\section{French}

Ferlus M. (1999). Les dialeces et les écritures des Tai (Thai) du Nghệ An (Vietnam). Treizièmes journées de linguistique d'asie orientale. CRLAO, Paris 1011 juin 1999.

Ferlus M. (2011). Les Băiyuè (百越) ou les “pays des horticulteurs/mangeurs de tubercules". 24ème Journées de Linguistique de l'Asie Orientale. 30 juin-1 juillet 2011, Paris.

\section{Chinese}

Hoàng Nhữ Huấn - Hoàng Hỷ (黄汝训-黄喆) (2005). Hoa Sonn nhai bich họa nghiên cúu (花山崖壁画研 究). Trung Quốc quảng bá điện thị xuất bản xã (中 国广播电视出版社).

Phạm Hồng Quý (范宏贵) (2005). Quảng Tây xã họi khoa hoc chuyên gia văn tập (广西社会科学专家文 集) - Phạm Hồng Quý tập (范宏贵集). Tuyến Trang thư cuc (线装书局).

Xu Song Shi (徐松石) (1946). Daizu, Zhuangzu,Yuezu kao (泰族徨族粵族考 [Research on the Tai, Zhuang and Yue]). Yongning, Zhonghua shuju. 


\title{
VÀI NÉT VỀ NGÔN NGỮ VĂN HÓA VIỆT NAM QUA GÓC NHİN ĐÔNG NAM Á
}

\author{
Trần Trí Dõi \\ Trường Đại học Khoa học Xã hội và Nhân văn, ĐHQGHN \\ 336 Nguyễn Trãi, Thanh Xuân, Hà Nội, Việt Nam
}

Tóm tắt: Là một quốc gia thuộc vùng Đông Nam Á, Việt Nam đồng thời cũng là một bức tranh thu nhỏ về ngôn ngữ văn hóa của khu vực. Những đặc điểm tiêu biểu nhất về ngôn ngữ văn hóa của nhiều quốc gia Đông Nam Á đều thấy hiện diện ở Việt Nam. Qua mô tả, so sánh và tiếp cận liên ngành, bài viết chỉ ra rằng do vị trí địa lý đặc biệt của Việt Nam, ở đây vẫn có những hiện tượng thể hiện ranh giới về nét khác biệt của ngôn ngữ văn hóa giữa những tiểu vùng khác nhau của Đông Nam Á. Do đó chúng thể hiện Việt Nam như là nơi trung chuyển của sự giao lưu về ngôn ngữ văn hóa giữa phía nam và phía bắc. Nói một cách khác, ở góc nhìn ngôn ngữ văn hóa, Việt Nam được coi như là cửa ngõ của sự tiếp xúc giữa các vùng Đông Á, Đông Nam Á và Nam Á.

Tù khóa: ngôn ngữ văn hóa, Việt Nam, Đông Nam Á 